\title{
Analisis Kapabilitas SIPKD BKD Kota Salatiga
}

\author{
Paulus Edward, Aprina Nugraheshty Sulistya Hapsari \\ Fakultas Ekonomika dan Bisnis \\ Universitas Kristen Satya Wacana \\ Salatiga, Indonesia \\ Email: 232015014@student.uksw.edu, esthy@staff.uksw.edu
}

\begin{abstract}
Regional Financial Agency (BKD) Salatiga is a government agency established in 2004 based on the National Regulation 32 year 2004 about Regional Government. In this globalization era, information systems are widely adopted, as global investment on information technology in 2022 is projected $\$ 4.2$ billion. But there are frauds occur, such as the vanish of customer of the Bank BRI and the leakage of ride sharing companies customer data. This study uses COBIT 5.0 framework. The first step is to identify stakeholder needs done by interview. The second step is to map the enterprise goals done by using balance scorecard. Then identify IT related goals (ITRG) and select human resources with five subdomains. The capability level approach is used on the domain of evaluate, direct, and monitor, the result shows that the BKD Salatiga got score of 2 (managed level).
\end{abstract}

Keywords: Capability Level, IT Management, COBIT 5, Badan Keuangan Daerah Kota Salatiga

\begin{abstract}
Abstrak
Badan Keuangan Daerah (BKD) Kota Salatiga adalah instansi pemerintah yang telah berdiri sejak 2004 atas keluarnya Undang-Undang Nomor 32 tahun 2004 tentang pemerintah daerah. Pada era globalisasi ini, sistem informasi tumbuh sangat pesat, dibuktikan dengan data yang menunjukkan perkiraan pengeluaran investasi teknologi informasi global pada tahun 2022 mencapai $\$ 4,2$ triliun namun fenomena yang terjadi justru makin maraknya kecurangan yang terjadi dalam pemanfaatan sistem informasi dan teknologi informasi ini seperti kasus hilangnya uang nasabah BRI dan bocornya data pengguna aplikasi transportasi online. Pada penelitian ini menggunakan COBIT 5.0 dengan pada tahap pertama melakukan identifikasi stakeholder needs dengan melakukan wawancara kemudian pada tahap selanjutnya memetakan enterprise goals menggunakan Balance Scorecard, lalu mengidentifikasi IT related goals (ITRG) serta memilih EDM sebagai fokus penelitian dengan kelima subdomain. Berdasarkan hasil penelitian evaluasi menggunakan pendekatan capability level pada domain Evaluate, Direct and Monitor, Badan Keuangan Kota Salatiga mendapatkan nilai rata-rata skor 2 yaitu mencapai level managed.
\end{abstract}

Kata kunci: Tingkat Kapabilitas, Tata Kelola IT, COBIT 5, Badan Keuangan Daerah Kota Salatiga 


\section{Pendahuluan}

Pada era globalisasi ini, sistem informasi tumbuh sangat pesat, dibuktikan dengan data Gartner Market Databook (1Q18 Update, 2018) yang menunjukkan perkiraan pengeluaran investasi TI (Teknologi Informasi) global pada tahun 2022 mencapai $\$ 4,2$ triliun. Hal tersebut menunjukkan bahwa baik teknologi informasi maupun sistem informasi di dalamnya sudah menjadi kebutuhan penting bagi masyarakat tidak terkecuali organisasi swasta dan publik. Namun fenomena yang terjadi justru makin marak kecurangan yang terjadi dalam pemanfaatan sistem informasi dan teknologi informasi ini. Contohnya kasus nasabah Bank BRI kehilangan uangnya yang disebabkan oleh penyadapan data nasabah melalui metoda skimming pada kartu ATM nasabah [2] Selain itu terdapat juga berita tentang bocornya data pengguna aplikasi transportasi online (Careem), akibat bocornya data pengguna aplikasi tersebut nama, alamat email, dan nomor telepon pengguna aplikasi online maupun driver telah dicuri. Hal ini terjadi akibat ada oknum yang menerobos masuk kedalam sistem peyimpanan data pada tanggal 14 Januari 2018 [3].

Dari fenomena diatas dapat diketahui bahwa dampak kerugian akibat lemahnya keamanan sistem informasi sangat besar. Risiko yang timbul dalam penggunaan sistem informasi ini seharusnya dapat dikurangi agar biaya-biaya akibat kehilangan data tidak membengkak dan tidak terjadi kembali di masa yang akan datang. Sistem informasi sendiri merupakan aset bagi organisasi sehingga aset tersebut harusnya dilindungi agar terhindar dari kerugian akibat pencurian maupun kerusakan, sehingga diperlukan langkah-langkah pencegahan dan kebijakan dari manajemen untuk pengamanan sistem informasi.

Pemerintah Kota Salatiga juga sudah mulai memanfaatkan teknologi dengan membuat beberapa sistem informasi untuk membantu pelayanan masyarakat Kota Salatiga. Badan Keuangan Daerah adalah salah satu contoh OPD yang sudah menggunakan sistem informasi untuk membantu walikota dalam pengelolaan keuangan daerah Kota Salatiga. Menurut laporan kinerja instansi pemerintah Kota Salatiga tahun 2017, dalam perjanjian kinerja Kota Salatiga tahun 2017 ingin meningkatan pelaksanaan reformasi birokrasi pemerintah daerah dalam menunjang kualitas pelayanan publik dengan target indeks 60, serta menganggarkan dana daerah untuk program pembangunan sistem informasi database jalan dan jembatan sebesar Rp200.000.000 [4]. Ini adalah perwujudan dari salah satu misi pemerintah Kota Salatiga untuk good governance dalam pengelolaan keuangan dan barang daerah yang profesional, terbuka dan bertanggung jawab. Hal tersebut menunjukkan bahwa pemerintah sudah concern terhadap pemanfaatan teknologi informasi dalam menunjang pelayanan kepada masyarakat sekaligus membantu kinerja pemerintah. 
AITI: Jurnal Teknologi Informasi

Volume 16 No. 1 Februari 2019, 65-87

Sistem informasi yang telah diimplementasikan perlu diperiksa dan dievaluasi secara berkala untuk menjamin integritas data sehingga data yang disajikan lengkap, baik dan benar, mengoptimalkan pemanfaatan sumberdaya secara efisien dan efektif yang mencakup software, hardware, SDM dan peralatan pendukung lainnya untuk membantu organisasi dapat mencapai tujuannya. Selain itu audit sistem informasi juga dapat dipakai sebagai alat untuk mengukur kesiapan dan kapabilitas suatu organisasi dalam pengelolaan sistem informasi.

Penelitian terdahulu dilakukan oleh Fajrin, Murahartawaty, \& Gumilang (2016) menyatakan bahwa belum optimalnya penggunaan TI dikarenakan adanya sistem yang belum terintegrasi, penyediaan informasi publik yang belum optimal, internet dan server yang sering bermasalah sehingga pemanfaatan TI yang diinvestasikan belum optimal. Penelitian ini menggunakan metodologi 7 lifecycle COBIT 5 dan hasil penelitiannya adalah tingkat kapabilitas BAPAPSI berada pada level 1 yaitu dengan kategori Partially Achieved pada domain EDM04 dan DSS01.

Penelitian sejenis dilakukan oleh Ciptaningrum, Nugroho, \& Adhipta (2015) pada kantor pemerintah Kota Yogyakarta menyatakan bahwa pemerintah Kota Yogyakarta belum pernah melakukan audit keamanan sistem informasi. Penelitian ini menggunakan lima proses pada COBIT 5 dengan responden berjumlah 9 orang. Hasil penelitian ini adalah Pemerintah Kota Yogyakarta belum menerapkan COBIT 5 sebagai kerangka kerja untuk keamanan sistem informasinya, kurangnya dokumentasian laporan, pendoman atau SOP untuk kebijakan terkait keamanan sistem informasi Kota Yogyakarta.

Sementara itu penelitian lain dilakukan oleh Abdul Hakim, Hoga Saragih (2014) yang menjadikan Kementrian ESDM sebagai bahan acuan penelitiannya menyatakan bahwa pengelolaan teknologi informasi lemah pada domain EDM dengan rata-rata level 2, selain itu juga lemahnya sub domain APO13 disebabkan kelemahannya dalam penanganan keamanan dalam pengelolaan IT dan masih terdapat kelemahan pada domain BAI akibat tidak adanya pendokumentasian yang memadai. Penelitian ini mengunakan framework COBIT 5 dan dalam pengumpulan data dengan metoda wawancara, kuesioner dan observasi.

Penelitian terkait audit sistem informasi juga dilakukan oleh Supradono[8] yang menjadikan perguruan tinggi swasta di Kota Semarang sebagai bahan acuan penelitiannya menyatakan bahwa tingkat kapabilitas penerapan pada perguruan tinggi di Kota Semarang pada level 3 (defined) dari skala 5 yang disyaratkan oleh COBIT 5. Terdapat 3 PTS yang memiliki tingkat kapabilitas pelayanan teknologi informasi tinggi, 5 PTS yang memiliki tingkat kapabilitas pelayanan teknologi informasi sedang dan 2 PTS yang memiliki tingkat kapabilitas pelayanan teknologi informasi rendah. Dari hasil GAP kapabilitas IT ditemukan bahwa rata-rata pelayanan TI pada tingkat 3 proses pelayanan TI sudah terdokumentasi dengan baik. 
Berdasarkan penelitian terdahulu oleh Azizah [9] yang menjadikan Unisnu Jepara sebagai bahan acuan penelitiannya menyatakan bahwa hasil tingkat kapabilitas pada implementasi terhadap e-learning pada Unisnu Jepara khusus domain DS pada level 4 pelayanan TI sudah terukur dan terintegrasi antara GAP antara kondisi yang diharapkan dengan kondisi saat ini dengan rata-rata 0,6 , tetapi masih terdapat kelemahan pada keamanan sistem dan memberikan pelatihan yang lebih intens. Penelitian ini menggunakan COBIT 4.1 khusus domain DS (deliver and support) dan wawancara dan kuisioner digunakan sebagai alat untuk pengumpulan data lapangan.

Berdasarkan beberapa penelitian terdahulu yang telah disebutkan di atas, penelitian ini bertujuan untuk menilai tingkat kapabilitas sistem informasi pada Badan Keuangan Daerah Kota Salatiga dengan menggunakan COBIT 5, khususnya pada domain Evaluate, Direct, and Monitor (EDM). BKD Salatiga dipilih menjadi objek penelitian karena dari wawancara awal dalam BKD terdapat sistem utama yaitu SIPKD (Sistem informasi penatausahaan keuangan daerah) sistem informasi tersebut memproses kembali output dari empat divisi yang dibawahinya yaitu: 1) Anggaran dan Belanja, 2) Manajemen barang milik daerah, 3) Bidang akuntansi dan pelaporan dan 4) Pendapatan Daerah. SIPKD digunakan sebagai objek audit karena hasil output dari sistem tersebut adalah laporan keuangan akuntansi BKD wajib untuk mempublikasi laporan keuangan akuntasi kepada publik dan belum diterapkan COBIT 5 sebagai sebagai acuan sistem informasi di BKD. Fokus penelitian yang dilakukan pada domain EDM karena untuk mengukur seberapa besar peran governance dalam mendukung kapabilitas SIPKD.

Hasil dari penelitian ini diharapkan dapat bermanfaat bagi pihak-pihak terkait seperti Badan Keuangan Daerah yang dapat menjadikan penelitian ini sebagai bahan evaluasi dalam tingkat kapabilitas atau kesiapan sistem informasi dalam pengelolaan informasi yang dipakai untuk pengambilan keputusan. Bagi pemerintah daerah, penelitian ini dapat digunakan sebagai pertimbangan dalam pengambilan keputusan terkait pembangunan sistem informasi dan sebagai solusi atas permasalahan yang terdapat pada Badan Keuangan Daerah. Bagi akademisi penelitian ini dapat menjadi referensi dan literatur terkait audit sistem informasi menggunakan framework COBIT 5.

\section{Kajian Pustaka}

\section{A. Good Governance}

Good governance merupakan proses terselenggaranya pemerintah yang bersih, adil, tertib dan pencapaian keputusannya dapat dipertanggungjawabkan dengan baik. Salah satu dari prinsip-prinsip good governance adalah transparansi, transparansi sendiri adalah keterbukaan atas kebijakan-kebijakan yang di ambil oleh pemerintah. Dengan adanya transparansi, pemerintah dapat meningkatkan 
AITI: Jurnal Teknologi Informasi

Volume 16 No. 1 Februari 2019, 65-87

kepercayaan kepada publik bisa melalui penyediaan sarana informasi maupun layanan publik yang akurat dan terpercaya.

Seluruh proses pemerintahan harus terbuka agar pihak-pihak yang berkepentingan dapat mengakses dan mendapatkan informasi yang dibutuhkan, salah satunya transparansi APBN maupun APBD yang dapat di akses bebas oleh masyarakat. Fenomena permasalahan yang sering terjadi di layanan pemerintah adalah prosedur pelayanan yang terlalu ribet, akses website pemerintah yang sering gangguan dan ketidakpastian waktu yang sering dikeluhkan oleh masyarakat.

Dengan adanya good governance dapat meningkatkan kinerja pelayanan publik karena semua proses kinerja pemerintah dapat diawasi oleh masyarakat melalui pengelolaan APBN maupun APBD sehingga kedepannya manager sektor publik dapat lebih kredibel kedepannya. Selain itu dapat mendukung good governance dengan menggunakan GEIT.

\section{B. Governance Enterprise of IT (GEIT)}

GEIT adalah segala hal yang berkaitan dengan kebijakan untuk menilai dan memastikan bahwa IT telah berjalan dengan baik. GEIT memungkinkan perusahaan untuk memanfaatkan TI sepenuhnya, memaksimalkan manfaat, memanfaatkan peluang dan agar mendapatkan keunggulan kompetitif.

Untuk dapat menerapkan GEIT, tantangan yang dihadapi oleh organisasi adalah output dari sistem informasi harus dapat dipertanggungjawabkan, sistem tersebut harus terdapat acuan (guide) dan manajemen harus sering mengenalkan IT kepada seluruh bagian organisasi. Terkadang penerapan GEIT juga dapat gagal dikarenakan GEIT tersebut tidak dipraktikan dan dikelola dengan baik di organisasi.

Dalam mencapai good governance, GEIT berperan sebagai tata kelola TI (IT Governance) yang baik. Tata kelola TI merupakan kesadaran manajemen untuk membuat satu kebijakan dimana terdapat proses pengelolaan terhadap penggunaan TI secara aman (secure), efektif dan efisien agar dapat dialokasikan penggunaan TI sesuai dengan tujuan organisasi. Tujuanny adalah untuk menyelaraskan antara modal yang sudah diinvestasikan dengan tujuan organisasi.

Untuk menilai kapabilitas IT Governance diperlukan audit sistem informasi. Audit sistem informasi adalah proses pengumpulan bukti untuk menilai kesiapan sistem komputer untuk dapat mengamankan aset, memelihara integritas data dan mendorong agar tercapainya organisasi secara efektif dan efisien dalam penggunaan sumber daya. Audit sistem informasi diperlukan untuk mengurangi risiko yang semakin tinggi dalam bidang sistem informasi seperti mendeteksi risiko kehilangan data, kurangnya perawatan terhadap perangkat keras dan output yang tidak sesuai yang diharapkan oleh manajemen.

\section{Framework COBIT 5}


Framework COBIT 5 adalah kerangka kerja yang digunakan untuk mengukur kesiapan dan kapabilitas suatu sitem informasi dalam organisasi. COBIT merupakan panduan kerangka kerja manajemen teknologi informasi yang dikeluarkan oleh IT Governance institute yang membantu auditor, pengguna dan manajemen senior untuk menjembati antara gap, risiko-risiko bisnis dan masalah teknis.

COBIT 5 merupakan versi terbaru dari perkembangan dari versi sebelumnya yaitu COBIT 4.0/4.1 dari ISACA, didalam COBIT 5 memiliki 37 proses dan mempunyai model proses tata kelola dan manajemen TI perusahaan yang dibagi menjadi dua domain proses utama yaitu: 1) Tata Kelola yang didalamnya terdapat domain Evaluate, Direct, dan Monitor (EDM), 2) Manajemen yang didalamnya memuat 4 domain sejajar dengan tanggung jawab dari Plan, Build, Run, and Monitor.

Domain di dalam COBIT 5 memiliki saling keterkaitan satu dengan lainnya, seperti yang nampak dalam Gambar 1 terdapat feedback antara proses dari governance dengan management. Gambar 1 menunjukkan proses dari governance, terdapat 3 domain utama yaitu evaluate, direct and monitor. Board of Director (BOD) pertama melakukan evaluasi terhadap kebutuhan bisnis sesuai dengan business needs organisasi. Lalu BOD akan memberikan pengarahan (Direct) kepada manajemen di bawahnya dalam bentuk kebijakan, regulasi maupun aturan yang berlaku.

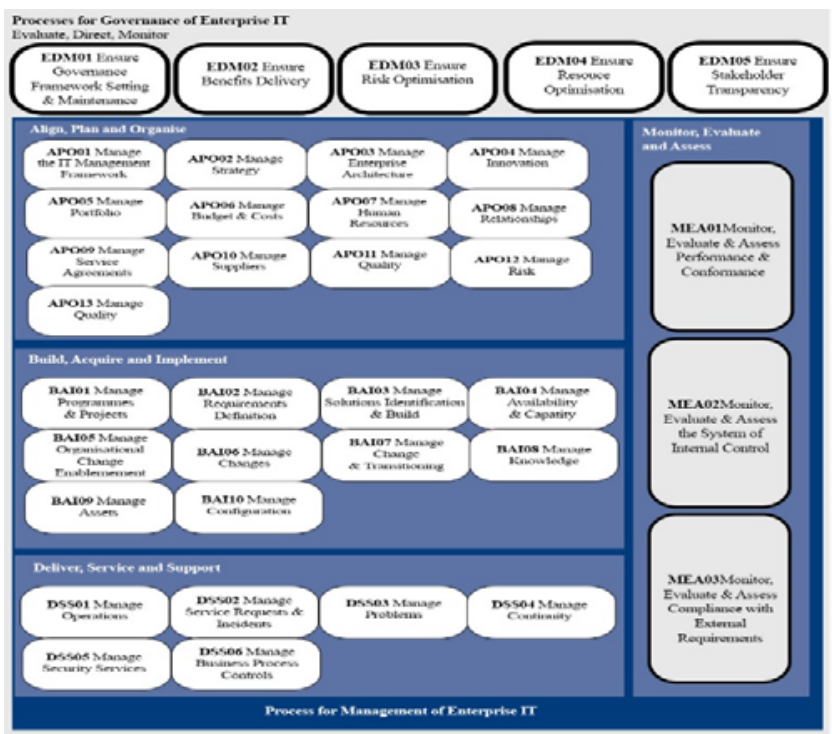

Gambar 1. COBIT 5 Governance and Management Key Areas. (Sumber: ISACA, 2013)

Dalam COBIT 5 terdapat 5 domain utama yaitu Align, Plan and Organise (APO), secara umum, pada domain ini meliputi strategi serta mengidentifikasi risiko dan memastikan bahwa IT dapat berkontribusi sesuai persyaratan untuk dapat tercapainya sasaran bisnis. Kedua adalah Build Acquire and Implement (BAI), 
AITI: Jurnal Teknologi Informasi

secara umum, pada domain ini terkait dengan pemeliharaan dan perubahan sistem yang ada agar dapat memenuhi tujuan bisnis. Ketiga adalah Deliver, Service and Support (DSS), domain DSS membahas tentang hasil proses IT dari layanan yang diminta. Domain ini mencakup area pengoperasian aplikasi dalam IT berjalan dan hasilnya serta dukungan pengoperasian sistem informasi dapat berjalan secara efektif dan efisien. Keempat adalah Monitor, Evaluate and Assess (MEA), domain ini mencakup kinerja manajemen untuk mengawasi, mengevaluasi dan memastikan bahwa sistem informasi dapat digunakan saat dibutuhkan seperti pelayanan untuk menggunakan sistem informasi, pengelolaan keamanan sistem informasi dan dukungan layanan bagi pengguna. Kelima adalah Evaluate, Direct and Monitor (EDM), secara umum, domain ini berisikan evaluasi dan monitor terhadap IT Governance yang terdapat pada kebijakan-kebijakan yang dibuat oleh stakeholder [9].

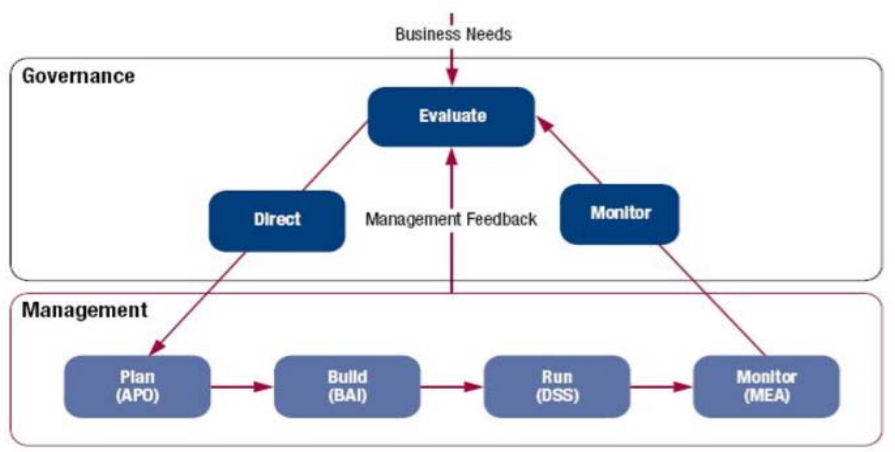

Gambar 2. Proses Pada COBIT 5 (Sumber : ISACA, 2013)

Gambar 2 menunjukkan keseluruhan dari 37 proses setiap domain COBIT 5 yang memiliki 5 proses tambahan dari pendekatan tata kelola IT dari COBIT 4.1. Pengukuran tingkat kapabilitas yang sudah diatur dalam COBIT 5 memudahkan manajer untuk mengukur seberapa baiknya pengelolaan IT dan kesiapan TI perusahaan, tingkat kemampuan pengelolaan IT dibagi menjadi 6 level yaitu [9] level 0 (Incomplete), pada level ini, perusahaan tidak memiliki atau tidak mengetahui proses-proses IT yang harusnya dimiliki untuk mencapai tujuan organisasi. Level 1 (Performed), pada level ini tujuan dan proses IT telah tercapai. Level 2 (Managed), pada level ini, kebijakan organisasi telah dibuat dan telah diimplementasikan dengan baik. Level 3 (Established), pada level ini, prosesproses IT yang telah diimplementasikan dengan baik dan telah terdapat standar operasi dalam seluruh ruang lingkup organisasi. Level 4 (Predictable), pada level ini, organisasi melakukan pengukuran proses yang dijalankan dalam batasanbatasan yang telah ditentukan. Level 5 (Optimizing), pada level ini, organisasi melakukan peningkatan secara berkelanjutan dan melakukan otomatisasi proses yang telah diimplementasikan oleh organisasi. 


\section{Metode Penelitian}

\section{A. Jenis Penelitian dan Teknik Pengumpulan Data}

Jenis penelitian yang digunakan pada penelitian ini adalah jenis penelitian kualitatif deskriptif dengan jenis data primer dan dokumentasi menggunakan pendekatan studi kasus di BKD Kota Salatiga. Penelitian ini menggunakan metoda wawancara dengan mewawancarai staff pranata komputer dan kasubbid pelayanan pengolahan data dan informasi serta melakukan dokumentasi dengan menganalisis dokumen-dokumen yang yang sudah ada untuk menguatkan temuan, seperti catatan-catatan yang berhubungan dengan penelitian, foto-foto, gambaran umum BKD dan struktur organisasi.

\section{B. Teknik Analisis Data}

Teknik analisis data yang digunakan pada penelitian ini pada tahap pertama adalah menentukan stakeholder needs yaitu melakukan wawancara dengan BKD yang bertujuan untuk menentukan tujuan strategis terkait output sistem informasi. Dari hasil wawancara tersebut peneliti dapat mengetahui target yang diinginkan oleh BKD dengan cara mereduksi data yang tidak diperlukan. Pada tahap selanjutnya memetakan enterprise goals yaitu hasil dari stakeholder needs akan dikaitkan dengan framework COBIT 5 yang berisikan 17 tujuan yang dikaitkan dengan balance scorecard. Pada tahap selanjutnya mengidentifikasi IT related goals (ITRG), hasil dari stakeholder needs dan enterprise goals adalah mengidentifikasi tujuan TI dan menentukan ITRG dengan mengidentifikasi primery dan secondary pada COBIT proses. Setelah menentukan primery dan secondary pada COBIT proses maka melakukan proses pada setiap sub domain, COBIT proses yang dipilih akan dipetakan ke dalam 37 proses COBIT. Pada penelitian ini difokuskan pada domain EDM. Pada tahap selanjutnya adalah merangkum setiap sub domain dan menentukan level kapabilitas dengan merangkum sub domain dan level kapabilitas dari hasil wawancara kuisioner dengan menggunakan expert judgement dari peneliti lalu akan ditarik kesimpulan dengan cara merangkum setiap domainnya untuk menarik kesimpulan dan akan menghasilkan tingkat kapabilitas dari pada setiap domainnya. Hasil level kapabilitas akan diberikan kepada BKD, hasil tersebut dapat menjadi pertimbangan BKD apakah akan melanjutkan perkembangan tata kelola sistem informasinya atau tidak. Jika pertimbangan BKD akan melanjutkan perkembangan tata kelola sistem informasinya maka peneliti akan membuat analisis gap untuk mengetahui hal apa saja yang dapat dilakukan oleh BKD agar dapat meningkatkan level kapabilitas yang diharapkan. 


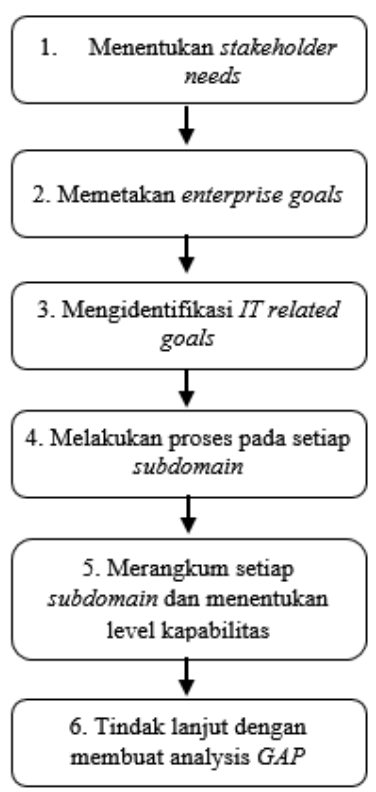

Gambar 3. Teknis Analisis Data

\section{Hasil dan Pembahasan}

\section{A. Gambaran Objek Penelitian}

Badan Keuangan Daerah (BKD) Kota Salatiga berdiri sejak 2004 atas diberlakukannya otonomi daerah di Indonesia serta diperkuat dengan keluarnya Undang-Undang Nomor 32 tahun 2004 tentang pemerintah daerah lalu diubah beberapa kali melalui Undang-Undang nomor 12 tahun 2008 dan peraturan pemerintah nomor 25 tahun 2000 tentang kewenangan pemerintah dan kewenangan propinsi sebagai daerah otonom. Lalu didirikan Dinas Pengelolaan Keuangan Daerah (DPKD) yang merupakan gabungan dari Dinas Pendapatan Daerah (DIPENDA) dan bagian keuangan Setda, selanjutnya menurut peraturan pemerintah nomor 41 tahun 2017 dan perda nomor 10 tahun 2008 tanggal 28 Oktober 2008 di bentuklah Dinas Pendapatan, Pengelolaan Keuangan dan Aset Daerah (DPPKAD) hasil gabungan DPKD dengan Bagian Pengelolaan Barang Daerah Setda kota Salatiga lalu menjadi Badan Keuangan Daerah (BKD) sesuai peraturan daerah kota salatiga nomor 9 tahun 2016 tentang pembentukan dan susunan perangkat daerah.Badan Keuangan Daerah kota salatiga memiliki 4 bidang yang sebelumnya memiliki 7 bidang meliputi : 1) Bidang pendapatan yang bertugas untuk melaksanakan fungsi penunjang keuangan urusan pemerintah yang menjadi kewenangan pemerintah daerah dilingkup pendapatan daerah; 2) Bidang akuntansi yang memiliki tugas untuk melaksanakan fungsi penunjang keuangan urusan pemerintah yang menjadi kewenangan pemerintah daerah dilingkup akuntansi daerah; 3) Bidang barang milik daerah yang memiliki tugas untuk melaksanakan fungsi penunjang keuangan urusan pemerintah yang menjadi kewenangan pemerintah daerah dilingkup pengelolaan barang daerah; 4) Bidang anggaran dan 
belanja fungsi penunjang keuangan urusan pemerintah yang menjadi kewenangan pemerintah daerah dilingkup anggaran dan belanja daerah.

Sistem informasi penatausahaan keuangan daerah (SIPKD) dibangun pada tahun 2008 atas diberlakukannya Kemendagri nomor 13 tahun 2006 yang dikembangkan bersama PT. Solusi Teknologi Informasi (STI) yang bergerak dibidang jasa konsultasi dan IT yang didirikan dengan nama PT. AdSis Multi Solusi sejak tahun 2003 yang masih berupa desktop base karena keterbatasan internet sehingga proses input masih menggunakan export import, pada tahun 2013 SIPKD mulai menerapkan web base, menggunakan akrual bases. SIPKD berada dikewenangan kepala badan yang memiliki unit dibawahnya yaitu kelompok jabatan fungsional pranata komputer. SIPKD bertujuan untuk menghasilkan menyajikan informasi keuangan daerah kepada pihak internal maupun external. Kelompok jabatan fungsional pranata komputer bertugas melakukan perekaman data, pemeliharaan data, pembetulan peralatan komputer dan jaringan. SIPKD merupakan sistem utama yang berada di Badan Keuangan Daerah Kota Salatiga, SIPKD memiliki subsistem dibawahnya yaitu 1) Bidang pendapatan terdapat tiga subsistem yaitu SIPD (Sistem Informasi Pengelolaan Pendapatan), SIPBB (Sistem Informasi Pajak Bumi dan Bangunan), dan SIBPHTB (Sistem Informasi Bea Perolehan Hak atas Tanah dan Bangunan); 2) Bidang anggaran dan belanja terdapat dua subbisnis yaitu anggaran menggunakan subsistem SIAPBD (Sistem Informasi Anggaran Pendapatan,dan Belanja Daerah) dan penatausahaan keuangan sistemnya berada di SIPKD; 3) Bidang barang milik daerah terdapat dua subsistem yaitu pengelolaan aset tetap menggunakan subsistem SIMBADA (Sistem Informasi Management Barang Daerah) dan barang persediaan dengan subsistem SIAP (Sistem Informasi Administrasi Persediaan); 4) Akuntansi pelaporan sistemnya include ke dalam SIPKD dan dari setiap subsistem tersebut mengeluarkan output yang itu menjadi input bagi SIPKD.

Di dalam struktur organisasi di BKD, yang bertanggung jawab atas SIPKD adalah kelompok jabatan fungsional yang didalamnya terdapat pranata komputer yang memiliki bertugas untuk melakukan perekaman data, pemeliharaan data, pembetulan peralatan komputer dan jaringan sesuai dengan prosedur yang berlaku agar pelaksanaan pekerjaan dapat berjalan sesuai dengan yang diinginkan, dan untuk struktur organisasi selanjutnya dapat dilihat pada Gambar 4. 
AITI: Jurnal Teknologi Informasi

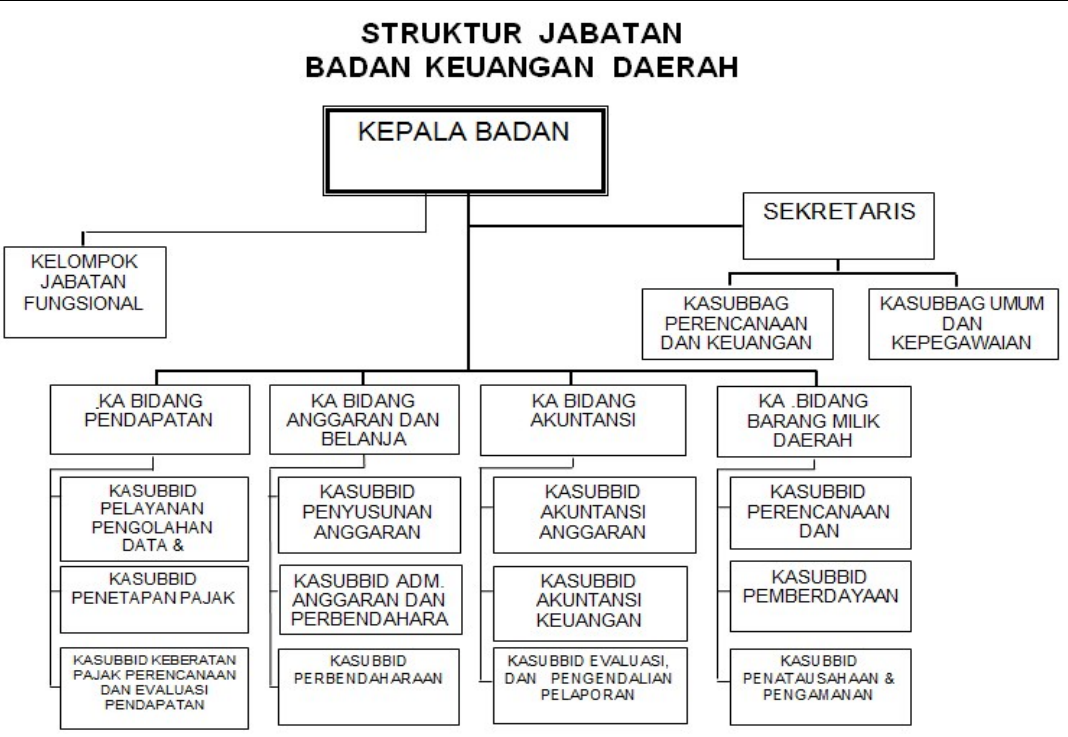

Gambar 4. Struktur Organisasi Badan Keuangan Daerah Kota Salatiga. (Sumber : Badan Keuangan Kota Salatiga, 2019)

Setelah mengetahui Struktuktur organisasi BKD, dapat dilihat pada Tabel 1 diambil 2 responden yang terkait SIPKD.

Tabel 1. TABEL RACI Badan Keuangan Daerah

\begin{tabular}{lll}
\hline Aktivitas Utama & Pranata Komputer & $\begin{array}{l}\text { Kasubbid } \\
\text { Pelayanan } \\
\text { Pengolahan } \\
\text { dan Informasi }\end{array}$ \\
\hline $\begin{array}{l}\text { Pemeliharaan dan Pengamanan } \\
\text { SIPKD }\end{array}$ & RA & RC \\
$\begin{array}{l}\text { Perekaman Data } \\
\text { Deteksi dan perbaiki kerusakan }\end{array}$ & RA & \\
$\begin{array}{l}\text { Data } \\
\text { Pemantauan SIPKD }\end{array}$ & R & \\
$\begin{array}{l}\text { Kontrol dan Dokumentasi Data } \\
\text { Membuat Laporan hasil Rekam }\end{array}$ & RA & R \\
$\begin{array}{l}\text { Data } \\
\text { Verifikasi Perekaman Data }\end{array}$ & RA & RC \\
$\begin{array}{l}\text { Pengaturan dan Perencanaan } \\
\text { Rapat }\end{array}$ & $\mathrm{C}$ & \\
$\begin{array}{l}\text { Pengarahan dan Monitoring } \\
\text { Membuat Laporan Pelaksanaan }\end{array}$ & $\mathrm{C}$ & $\mathrm{RC}$ \\
Tugas Kepada Atasan & & RA \\
\hline
\end{tabular}

B. Identifikasi Stakeholder Needs

Pada tahap pertama yang dilakukan untuk menentukan tingkat kapabilitas menggunakan kerangka kerja COBIT 5 perlu identifikasi stakeholder needs untuk 
mengetahui tujuan perusahaan terkait membangun IT dalam organisasinya. COBIT 5 menyediakan Kartu Dimensi Nilai Keseimbangan (Balanced Scorecard) yang dikategorikan menjadi 17 tujuan perusahaan (Enterprise Goals) dalam empat dimensi, yaitu dimensi Keuangan (Financial), Pelanggan (Customer), Proses Bisnis Internal (Internal) dan yang terakhir adalah Belajar dan Bertumbuh (Learn and Growth). BKD Kota Salatiga memiliki lima tujuan bisnis yaitu: (1) Mengacu peraturan Kemendagri nomor 13 tahun 2006 tentang pedoman pengelolaan daerah; (2) Mengintegrasi data antar subsistem; (3) Menghasilkan data yang lebih akuntabel dan transparan; (4) Penggunaan waktu yang lebih efisien dan efektif; (5) Pengembangan SI secara berkala untuk mengikuti perkembangan regulasi.

Tabel 2. Pemetaan Stakeholder Needs ke Enterprise Goals

\begin{tabular}{|c|c|c|}
\hline Stakeholder Needs & $\begin{array}{l}\text { BSC } \\
\text { Dimension }\end{array}$ & Enterprise Goals \\
\hline $\begin{array}{l}\text { Mengacu peraturan Kemendagri } \\
\text { no } 13 / 2006\end{array}$ & Financial & $\begin{array}{l}\text { Compliance with } \\
\text { esternal laws and } \\
\text { regulations }\end{array}$ \\
\hline \multirow[t]{2}{*}{ Integrasi data antar OPD } & Fiancial & $\begin{array}{l}\text { Managed business risk } \\
\text { (safe guarding assets) }\end{array}$ \\
\hline & Customer & $\begin{array}{l}\text { Optimisation of service } \\
\text { delivery costs }\end{array}$ \\
\hline \multirow[t]{3}{*}{$\begin{array}{l}\text { Data yang dihasilkan lebih } \\
\text { akuntabel dan transparan }\end{array}$} & Financial & $\begin{array}{l}\text { Managed business risk } \\
\text { (safe guarding assets) } \\
\text { Financial transparency }\end{array}$ \\
\hline & Customer & $\begin{array}{l}\text { Customer oriented } \\
\text { service culture }\end{array}$ \\
\hline & Internal & $\begin{array}{lr}\text { Optimisation } & \text { of } \\
\text { business } & \text { process } \\
\text { functionality } & \end{array}$ \\
\hline $\begin{array}{l}\text { Penggunaan waktu yang lebih } \\
\text { efisien dan efektif }\end{array}$ & Internal & $\begin{array}{l}\text { Optimisation of } \\
\text { business process costs }\end{array}$ \\
\hline & & $\begin{array}{l}\text { Operational and staff } \\
\text { productivity }\end{array}$ \\
\hline \multirow[t]{2}{*}{$\begin{array}{l}\text { Perkembangan SI secara berkala } \\
\text { untuk mengikuti perkembangan } \\
\text { regulasi }\end{array}$} & Financial & $\begin{array}{l}\text { Compliance with } \\
\text { external laws and } \\
\text { regulations }\end{array}$ \\
\hline & $\begin{array}{l}\text { Learn and } \\
\text { Growth }\end{array}$ & $\begin{array}{l}\text { Product and business } \\
\text { innovation culture }\end{array}$ \\
\hline
\end{tabular}

Pada stakeholder needs pertama BKD memiliki kebutuhan untuk dapat mengikuti aturan pemerintah melalui SIPKD, yaitu terkait dengan peraturan Kemendagri nomor 13 tahun 2006 yang berisi tentang pedoman pengelolaan daerah yang ditujukan untuk setiap BKD. Selanjutnya BKD juga menyesuaikan dengan aturan Kemendagri nomor 910/1866/SJ dan 910/1867/SJ tentang transaksi non tunai seperti belanja dan pendapatan. Hal ini terkait erat dengan dimensi finansial, 
AITI: Jurnal Teknologi Informasi

Volume 16 No. 1 Februari 2019, 65-87

khususnya dalam hal ketaatan pada hukum dan aturan yang berlaku. Organisasi publik akan lebih rentan dan ketat terhadap aturan-aturan yang diterapkan oleh pemerintah, sehingga dalam implementasi sistem informasinya harus fleksibel untuk memenuhi ketaatan terhadap aturan yang berlaku.

Selanjutnya pada Stakeholder needs kedua terkait terintegrasinya data antar subsistem diharapkan adanya sharing data antar lingkungan kerja di BKD, selain itu juga dapat menghemat biaya perjalanan untuk menyatukan data dari seluruh subsistem yang ada. Hal ini sesuai dengan hasil wawancara dengan narasumber.

"SIPKD dari tahun 2008 sampai saat ini terus berkembang, pertama kali muncul belum terintegrasi, aplikasi itu masih diinstal di komputer standalone jadi untuk pooling data nya harus di export dan disimpan di flashdisk tetapi mulai tahun 2013 kita intergrasikan dari yang desktop base ke web base sementarakan dulu tahun 2008 infrastruktur untuk internet belum bagus, jadi untuk bergerak ke sana berat, tapi mulai tahun 2013 IT pemda upgrade kita integrasikan semuanya"

Hal ini terkait erat dengan dimensi pelanggan, khususnya dalam hal optimisasi biaya layanan pengiriman. Dengan terintegrasinya data juga dapat terhindar dari adanya duplikat data. Hal ini terkait erat dengan dimensi finansial, khususnya dalam hal management risiko bisnis.

Pada Stakeholder needs ketiga BKD sebagai pelayan publik harus mengikuti Undang-Undang Republik Indonesia Nomor 14 tahun 2008 tentang keterbukaan informasi publik yang berisi pada Pasal 3 tentang mewujudkan penyelenggaraan negara yang baik, yaitu transparan, efektif dan efisien.

“Transaksi di SIPKD dari belanja dan pendapatan sudah non tunai, dari sisi pendapatan kan misalnya pajak daerah dan retribusi daerah dibuat transaksi non tunai kan dari sisi wajib pajak tingkat kepercayaan terhadap pemerintah daerah meningkat memang karena tidak ada petugas yang membaca istilahnya membawa uang pajak untuk distorkan tetapi wajib pajak sendiri yang bayar di bank, jadi meningkatkan akuntabilitas dan lebih transparan”

Hal tersebut berkaitan erat dengan dimensi financial, khususnya dalam hal ketaatan pada hukum dan aturan yang berlaku dan laporan keuangan yang transparan. Pada Pasal 3 juga BKD sebagai organisasi publik harus meningkatkan pengelolaan dan pelayanan informasi di lingkungan badan publik untuk menghasilkan layanan informasi yang berkualitas. Hal ini berkaitan erat dengan dimensi pelanggan, khususnya dalam hal budaya yang berorientasi layanan kepada pelanggan (masyarakat) agar informasi yang dihasilkan akuntabel serta dapat 
dipertanggungjawabkan sehingga data yang dihasilkan lebih akuntabel dan transparan karena seluruh datanya sudah terintegrasi sehingga data-data tersebut dapat dipertanggungjawabkan. Hal ini juga berkaitan erat dengan dimensi Proses Bisnis Internal, khususnya optimalisasi fungsi proses bisnis.

Selanjutnya pada Stakeholder needs keempat tujuan BKD membuat SIPKD juga dapat membuat penggunaan sumberdaya seperti penggunaan waktu dan sumberdaya manusia lebih efektif dan efisien sehingga waktu yang digunakan untuk menginput data yang dilakukan oleh staf lebih cepat dan akurat. Hal ini berkaitan erat dengan dimensi Proses Bisnis Internal, khususnya dalam optimalisasi biaya proses bisnis dan produktivitas operasional dan staf.

Pada Stakeholder needs terakhir, untuk mengikuti regulasi pemerintah khususnya jika terdapat terdapat aturan-aturan baru yang dikeluarkan oleh pemerintah pusat, hal ini berkaitan erat dengan dimensi finansial, khususnya dalam hal ketaatan pada hukum dan aturan yang berlaku sehingga BKD harus mampu untuk mengikuti aturan-aturan tersebut seperti pajak rumah makan yang pada tahun 2019 akan terintegrasi oleh SIPKD sehingga BKD selalu melakukan inovasi untuk memperbaharui SIPKD secara berkala dan dibuat secara fleksibel. Hal ini berkaitan dengan dimensi Belajar dan Bertumbuh, khususnya budaya inovasi produk dan bisnis.

"Harapannya, jadi ditahun 2019 SIPKD harus ada update lagi untuk mengikuti kebijakan yang ada, saat ini kan misalnya pajak rumah makan, pajak daerah dari transaksi makan dan minum ke rekanan, pajaknya belum dipungut sekalian nanti akan diterapkan ditahun ini jadi nanti ada update lagi”

\section{Pemetaan Enterprise Goals dan IT Related Goals}

Setelah melalui tahapan identifikasi 5 stakeholder needs BKD terkait SIPKD, tahap berikutnya yaitu pemetaan tujuan perusahaan dengan tujuan yang terkait IT yang hasilnya terdapat pada Lampiran 3. Pemetaan Enterprise Goals dan IT Related Goals bertujuan untuk mengidentifikasi proses yang paling dekat terkait dengan tujuan IT menggunakan processes capability model (PCM) yang dibagi menjadi 2 kategori yaitu, Primary (P) dan Secondary (S). Primary menunjukkan bahwa item tersebut memiliki prioritas tinggi, sedangkan secondary menunjukkan bahwa item tersebut memiliki prioritas terendah. Dari hasil pemetaan IT Related Goals dengan Enterprise Goals, yang dilihat hanya pada prioritas tinggi.

Pada domain financial terpilih 3 COBIT proses yang terkait manajemen risiko bisnis yaitu mengatur risiko bisnis terkait IT, keamanan informasi, pemrosesan infrastruktur dan aplikasi dan staf bisnis dan IT yang kompeten dan bermotivasi. Ketiga COBIT proses tersebut terkait dengan manajemen risiko bisnis karena untuk menilai sejauh mana suatu kejadian atau keadaan dapat mengganggu 
AITI: Jurnal Teknologi Informasi

Volume 16 No. 1 Februari 2019, 65-87

proses bisnis, menilai sejauh mana kesiapan infrastruktur IT dan aplikasi untuk menunjang proses bisnis sehingga dapat mengurangi risiko bisnis di masa depan, dan untuk menilai sejauh mana kompetensi, kesiapan dan motifasi staf dalam menunjang IT untuk mengurangi risiko bisnis terkait IT.

Selanjutnya pada domain financial terpilih 3 COBIT proses yang terkait pemenuhan kebutuhan terkait hukum dan regulasi pemerintah yaitu kepatuhan dan dukungan IT untuk kepatuhan bisnis dengan hukum dan peraturan eksternal, keamanan informasi, pemrosesan infrastruktur dan aplikasi, dan kepatuhan IT terkait kebijakan internal. Ketiga COBIT proses tersebut terkait dengan pemenuhan kebutuhan terkait hukum dan regulasi pemerintah karena untuk memenuhi kepatuhan aturan pemerintah sebagai perusahaan badan milik pemerintah dan aturan internal yang dimiliki oleh BKD. Terakhir pada domain financial terkait laporan keuangan yang transparan hanya memiliki 1 COBIT proses yaitu transparansi biaya, manfaat, dan risiko IT karena pentingnya melaporkan performa dengan stakeholder terkait biaya, manfaat dan risiko IT yang dapat mengganggu tujuan BKD.

Pada domain customer terpilih 2 COBIT proses terkait budaya bisnis yang berorientasi layanan yaitu penyelarasan IT dan strategi bisnis dan pemenuhan layanan TI sesuai dengan persyaratan bisnis. Kedua COBIT proses tersebut terkait budaya bisnis yang terkait layanan karena untuk memastikan bahwa IT dapat memberikan dukungan yang baik dan berkualitas untuk memastikan bahwa layanan di BKD dapat menghasilkan layanan informasi bagi stakeholder yang berkualitas.

Selanjutnya pada domain customer terpilih 2 COBIT proses terkait optimalisasi biaya pengiriman layanan yaitu transparansi biaya, manfaat, dan risiko IT dan optimalisasi aset, sumber daya, dan kemampuan IT. Kedua COBIT proses tersebut terkait optimalisasi biaya pengiriman layanan karena dapat membantu BOD untuk melakukan estimasi biaya dan melakukan evaluasi sehingga tidak melakukan hal yang sama yang dapat menghambat mencapai tujuan BKD dan membuang sumberdaya secara tidak efisiensi.

Pada domain internal terpilih 5 COBIT proses terkait optimalisasi fungsi proses bisnis pertama adalah penyelarasan IT dan strategi bisnis agar BKD dapat meningkatkan efisiensi, mengurangi biaya, dan menciptakan strategi bisnis baru, IT juga dapat menjadikan BKD lebih kompetitif dan dapat meningkatan kualitas dan otomatisasi proses. Kedua adalah pemenuhan layanan IT sesuai dengan persyaratan bisnis agar keberlangsungan kinerja BKD dalam memenuhi tugas dalam memberikan layanan informasi dapat tercapai dan proses yang ada dapat lebih dioptimalkan dan efisien. Ketiga adalah informasi dan solusi teknologi yang memadai, dalam memenuhi kewajiban BKD dalam memberikan layanan informasi berbasis IT diperlukan informasi yang akuntabel dan solusi teknologi yang memadai agar dapat mengoptimalkan operasi bisnis di BKD. Keempat adalah 
kelincahan IT untuk mengukur seberapa efisien infrastruktur IT di BKD dapat memenuhi kebutuhan eksternal. Dan terakhir adalah pemberdayaan dan dukungan proses bisnis dengan mengintegrasikan aplikasi dan teknologi ke dalam proses bisnis dengan adanya integrase antar aplikasi dan teknologi dapat membuat penggunaan sumberdaya lebih efektif dan efisien dan dapat mengoptimalkan biaya perjalanan.

Selanjutnya pada domain internal terpilih 3 COBIT proses terkait optimalisasi biaya proses bisnis yaitu pertama adalah realisasi manfaat dari portofolio investasi dan layanan yang diberikan oleh IT agar memastikan bahwa investasi TI memberikan manfaat yang disepakati terhadap strategi dengan risiko yang disepakati dan juga dapat berkonsentrasi pada pengoptimalan sumber daya agar dapat mengoptimalkan biaya yang keluar. Kedua adalah transparansi biaya, manfaat, dan risiko IT agar BOD dapat melakukan estimasi biaya proses bisnis dan melakukan evaluasi dan terakhir adalah optimalisasi aset, sumber daya, dan kemampuan IT agar dapat menghasilkan keselarasan antara tujuan TI dengan tujuan bisnis dan dapat lebih mengembangkan aset, sumber daya dan IT yang ada di BKD.

Selanjutnya pada domain internal terpilih 2 COBIT terkait produktivitas operasional dan staf yaitu penggunaan aplikasi, informasi, dan solusi teknologi yang memadai untuk menunjang produktivitas BKD dalam menyajikan informasi keuangan dan staff dan TI yang kompeten dan bermotivasi untuk membangkitkan staff yang berkontributif, kreatif dan loyal dalam pekerjannya serta memiliki kompetensi yang cukup untuk mengelola IT di BKD.

\section{Pemetaan IT Related Goals Terhadap EDM}

Setelah melalui tahapan pemetaan tujuan perusahaan terhadap tujuan terkait IT, tahap berikutnya yaitu memetakan IT Related Goals terhadap domain EDM yang hasilnya pada lampiran 4. Pemetaan IT Related Goals terhadap EDM bertujuan untuk melihat peran governance khususnya BOD di BKD yaitu kepala badan BKD bapak Adi Isnanto dalam mendukung kapabilitas SIPKD. Pada hasil pemetaan IT Related Goals terhadap COBIT proses pada domain EDM terpilih 5 proses COBIT. Pada proses EDM 01 bertujuan untuk menganalisa keperluan tata kelola IT yang konsisten terintegrasi dan selaras dengan strategi, tujuan dan pemeliharaan keefektifan struktur yang ada. Lalu pada proses EDM 02 bertujuan untuk memastikan bahwa pengamanan nilai optimal dari pengadaan IT, servis, dan aset, melalui efisiensi biaya dan solusi IT dari hasil investasi IT oleh perusahaan. Pada proses EDM 03 bertujuan agar memastikan bahwa risiko IT perusahaan tidak melebihi kemampuan dan toleransi yang telah ditetapkan oleh perusahaan serta dikomunikasikan dan melakukan pengidentifikasi risiko yang berhubungan dengan IT. Lalu pada proses EDM 04 bertujuan memastikan sumber daya yang dibutuhkan perusahaan dapat terpenuhi secara optimal sehingga dapat mendukung tujuan perusahaan dengan biaya IT yang optimal. Terakhir pada proses EDM 05 bertujuan 
AITI: Jurnal Teknologi Informasi

Volume 16 No. 1 Februari 2019, 65-87

agar terdapat komunikasi yang efektif serta melaporkan performa dan hasil IT kepada stakeholder secara transparan.

\section{E. Maturity Level}

Tabel 3. Temuan Penelitian

\begin{tabular}{ll}
\hline Proses COBIT 5 & Temuan Saat Ini \\
\hline EDM01 & (1) SOP atau standar yang mengatur untuk pengoperasian \\
(Evaluasi Kerangka Tata & SIPKD belum tercantumkan, SOP hanya mengatur \\
Kelola dan Pemeliharaan & $\begin{array}{l}\text { operasional BKD dan untuk SIPKD hanya terdapat user } \\
\text { manual saja. }\end{array}$ \\
IT) & $\begin{array}{l}\text { (1) Belum ada job desk dan tanggungjawab yang jelas } \\
\text { EDM 02 }\end{array}$ \\
(Evaluasi Pengamanan & untuk melakukan pengamanan nilai optimal pengadaan IT. \\
nilai optimal pengadaan &
\end{tabular}

IT)

EDM 03

(1) Belum ada aturan khusus untuk staf melakukan (Evaluasi pengoptimalan pengoptimalan risiko IT hanya by case.

risiko)

(2) SOP atau standar yang mengatur untuk pengoptimalan risiko IT belum tercantumkan, SOP hanya mengatur operasional.

EDM 04

(1) Kurangnya pengembangan kapasitas SDM.

(Evaluasi optimalisasi (2) Pelaksanaan prinsip-prinsip manajemen sumber daya sumber daya) belum konsisten.

(3) Belum adanya pengugasan yang jelas terkait optimalisasi sumber daya.

EDM 05

(1) Dalam pembuatan laporan SIPKD masih suka terjadi (Evaluasi pelaporan yang masalah internal seperti sering salah input karena sering transparansi kepada adanya mutasi pegawai yang sudah dilatih diganti dengan stakeholder) yang baru.

(2) Belum adanya pembuatan laporan khusus terkait performa IT.

(3) Proses pelaporan sudah direncanakan tapi belum dipantau/diatur karena job desk staff IT yang belum jelas.

\section{F. Analisis Kesenjangan}

Melihat dari tingkat kapabilitasnya, tahap berikutnya adalah pembuatan analisis kesenjangan yang bertujuan untuk mengetahui seberapa besar kesenjangan kondisi organisasi saat ini dibandingkan dengan kondisi yang diharapkan serta kondisi optimal dari sebuah proses tata kelola IT.

Kondisi ideal yang diharapkan BKD adalah level 4 (Predictable) yaitu kondisi dimana organisasi sudah melakukan proses pengukuran yang dijalankan dalam batasan-batasan yang telah disepakati oleh BKD dengan cara membuat SOP atau standar yang jelas serta adanya management sumberdaya manusia yang baik untuk proses kinerja SIPKD. 
Dari hasil penilaian, terdapat kesenjangan antara kondisi yang ingin dicapai dengan kondisi saat ini. Hal tersebut dapat dilihat tabel dan gambar berikut :

Tabel 4. Gap Analisis Dan Rekomendasi

\begin{tabular}{llll}
\hline & $\begin{array}{l}\text { Kondisi } \\
\text { Saat Ini }\end{array}$ & Target & Optimal \\
\hline EDM & 3 & 4 & 5 \\
01 & & & \\
& & & \\
& & & \\
& & & \\
& & & \\
EDM & 2 & 4 & 5 \\
02 & & & \\
\end{tabular}

(1) Adanya SOP terkait pengoperasian SIPKD diimplementasikan dan dievaluasi kembali.

(2) SOP mengatur tentang persyaratan dan tahapan melakukan dokumentasi terhadap SIPKD dan dikontrol oleh BKD.

(3) SOP mengatur infrastruktur yang diperlukan untuk menjalankan SIPKD

(4) Menggunakan pengukuran statistik dari tujuan dan prosedur lalu dianalisis dan dikontrol.

(5) Melakukan teknik analisis dan kontrol untuk memastikan batas kontrol variansi dan dikoreksi jika dibutuhkan.

(1) Mengevaluasi mutase pegawai untuk lebih efisien dan efektif yang sesuai dengan kebutuhan BKD agar menciptakan pegawai yang berkualitas dan kapabilitas pegawai IT dapat terpenuhi.

(2) Terdapat pemisahan tugas dan tanggung jawab yang jelas, diatur, dikontrol dan di implementasikan melalui SOP yang ada.

(3) Melakukan manajemen sumber daya untuk melakukan pengamanan aset SIPKD beserta job desk yang jelas dalam melakukan dokumentasi saat melakukan pengamanan nilai aset SIPKD.

(4) SOP mengatur tentang persyaratan, pedoman saat melakukan dokumentasi dan kontrol.

(5) SOP mengatur pedoman, pendefinisian unsur-unsur fundamental yang harus dilakukan dalam melakukan pengamanan nilai aset SIPKD.

(6) Melakukan pengukuran proses kinerja dalam pengamanan nilai aset SIPKD dan langkah-langkah proses pengukuran diketahui dan diatur serta hasil pengukuran dianalisis dan dilaporkan.

(7) Melakukan teknik analisis dan kontrol untuk menggambarkan pengamanan nilai aset 
AITI: Jurnal Teknologi Informasi

Volume 16 No. 1 Februari 2019, 65-87

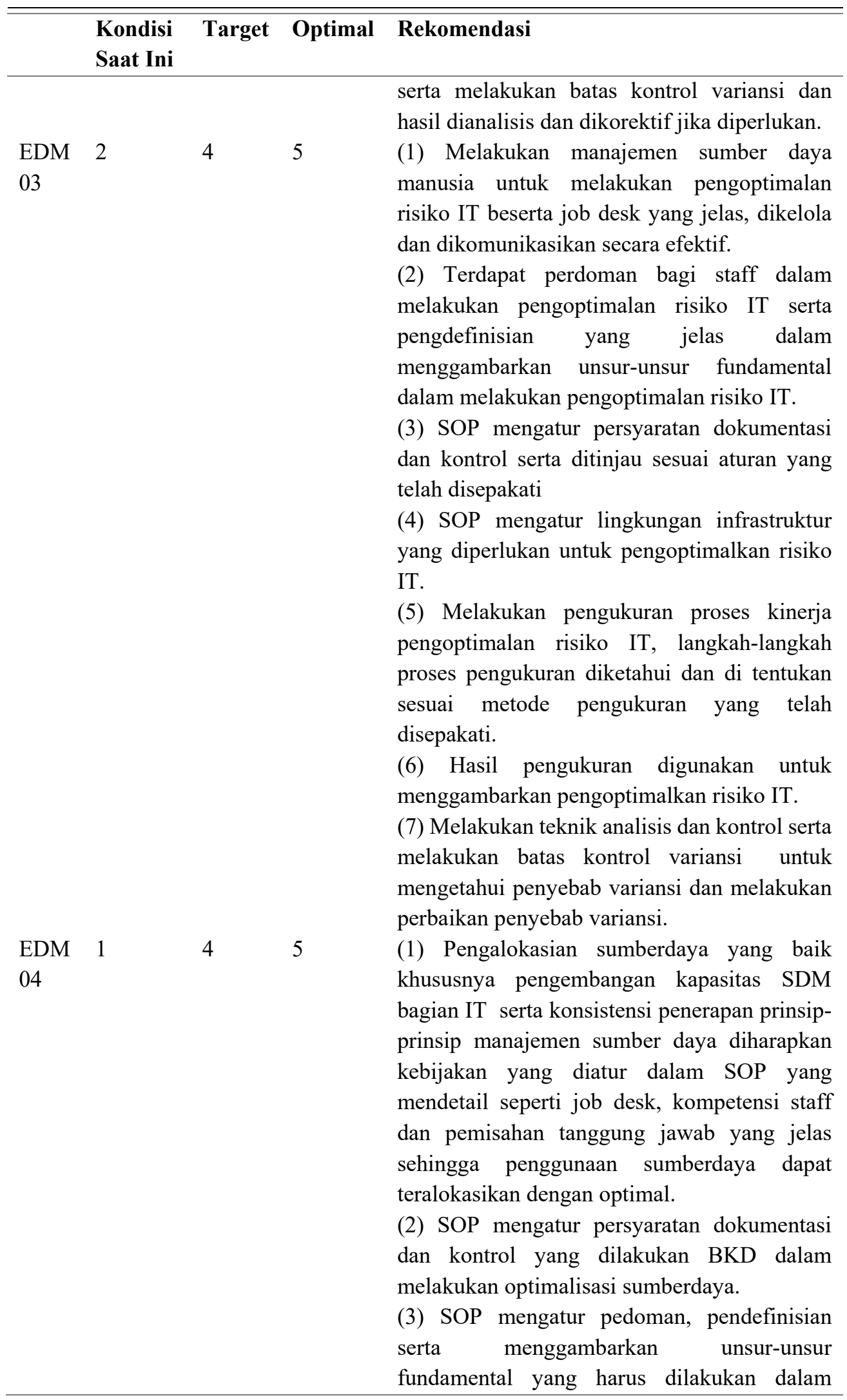




\begin{tabular}{|c|c|c|c|c|}
\hline & $\begin{array}{l}\text { Kondisi } \\
\text { Saat Ini }\end{array}$ & Target & Optimal & Rekomendasi \\
\hline $\begin{array}{l}\text { EDM } \\
05\end{array}$ & 2 & 4 & 5 & $\begin{array}{l}\text { melakukan optimalisasi sumberdaya secara } \\
\text { mendetail. } \\
\text { (4) SOP mengatur lingkungan infrastruktur } \\
\text { yang dibutuhkan dalam melakukan } \\
\text { optimalisasi sumber daya. } \\
\text { (5) Melakukan metode untuk melakukan } \\
\text { pemantauan optimalisasi sumberdaya. } \\
\text { (6) Melakukan pengukuran proses kinerja } \\
\text { pengoptimalan sumberdaya, langkah-langkah } \\
\text { proses pengukuran diketahui dan di tentukan } \\
\text { sesuai metode pengukuran yang telah } \\
\text { disepakati. } \\
\text { (7) Melakukan teknik analisis dan kontrol serta } \\
\text { melakukan batas kontrol variansi untuk } \\
\text { mengetahui penyebab variansi dan melakukan } \\
\text { perbaikan penyebab variansi. } \\
\text { (1) Meningkatkan kualitas pelaporan yang } \\
\text { lengkap, tepat waktu dan akurat terutama } \\
\text { dalam keakuratan data dalam melakukan input } \\
\text { data yang dilakukan oleh staff. } \\
\text { (2) Melakukan pemantauan proses pelaporan } \\
\text { agar sesuai dengan tujuan perusahaan } \\
\text { (3) Melakukan pembagian job desk yang jelas } \\
\text { dalam pembagian tugas dan tanggunjawab } \\
\text { dalam melakukan pelaporan yang transparansi. } \\
\text { (4) SOP mengatur standar pelaporan yang } \\
\text { secara transparansi serta berisikan pedoman, } \\
\text { pendefinisikan unsur-unsur fundamental yang } \\
\text { harus dilakukan.. } \\
\text { (5) SOP mengatur infrastruktur yang } \\
\text { diperlukan dalam pembuatan laporan yang } \\
\text { transparansi. } \\
\text { (6) ) Melakukan pengukuran proses kinerja } \\
\text { pembuatan pelaporan yang transparansi, } \\
\text { langkah-langkah proses pengukuran diketahui } \\
\text { dan di tentukan sesuai metode pengukuran } \\
\text { yang telah disepakati. } \\
\text { (7) Melakukan teknik analisis dan kontrol serta } \\
\text { melakukan batas kontrol variansi untuk } \\
\text { mengetahui penyebab variansi dan melakukan } \\
\text { perbaikan penyebab variansi. }\end{array}$ \\
\hline
\end{tabular}

Tabel 4 menunjukkan kondisi saat ini EDM01 di BKD berada di level 3 karena sudah terdapat jaminan atau kepastian yang diperoleh BKD agar SIPKD 
AITI: Jurnal Teknologi Informasi

dapat berjalan dengan efektif lalu proses prosedur operasional sudah dikelola dengan baik seperti pemantauan kinerja, pemisahan tugas dan sumberdaya yang dibutuhkan untuk mengoperasikan SIPKD dan sudah terdapat standar yaitu juklak juklis serta kontrol dan dokumentasi yang sudah dikerjakan.

Pada kondisi saat ini EDM02 berada pada level 2 karena BKD sudah mampu mengamankan nilai aset SIPKD serta proses pengamanan aset sudah direncakan dan dipantau melalui rapat tahunan .

Pada kondisi saat ini EDM 03 berada di level 2 karena BKD sudah merencanakan dan memantau serta dapat mengatasi risiko yang sering muncul dan risiko yang muncul tidak melebihi risk appetite.

Pada kondisi saat ini EDM 04 berada di level 1 karena belum terpenuhinya kebutuhan sumberdaya manusia yang optimal dalam menjalanan SIPKD dan belum konsistennya penerapan prinsip-prinsip manajemen sumberdaya.

Pada kondisi saat ini EDM 05 berada di level 2 karena sudah terdapat dasar untuk laporan kepada stakeholder dan komunikasi yang efektif dengan stakeholder. Hasil laporan SIPKD sudah direncanakan dan dipantau secara transparansi serta sudah terdapat pemisahan tanggung jawab dan otoritas yang baik untuk pembuatan laporan kepada stakeholder.

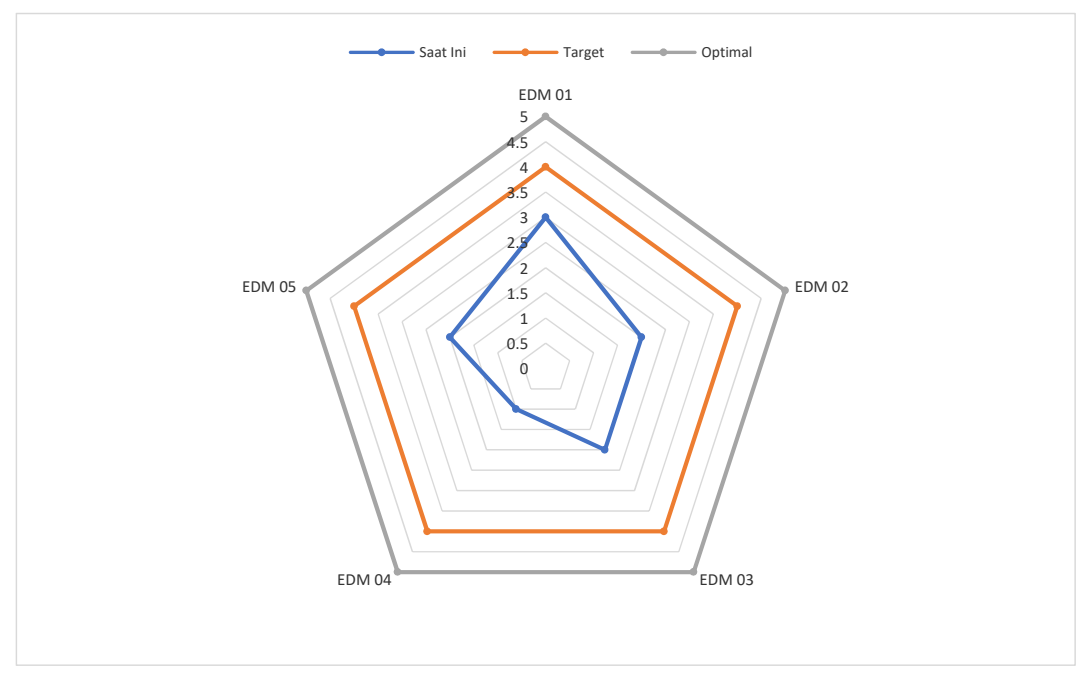

Gambar 5. Diagram Kesenjangan Level Yang Dicapai Saat Ini Dengan Target Level

\section{Simpulan}

\section{A. Simpulan}

Berdasarkan hasil penelitian evaluasi menggunakan pendekatan capability level pada domain Evaluate, Direct and Monitor mendapatkan nilai rata-rata skor 2 (managed) yang artinya pada level ini, kebijakan organisasi telah dibuat dan telah diimplementasikan dengan baik. Hal ini dikarenakan belum adanya SOP secara 
tertulis yang mengatur alur kerja SIPKD dan masih lemahnya pengelolaan sumber daya manusia yang ada di BKD Kota Salatiga, khususnya yang terkait dengan pengelolaan SIPKD.

\section{B. Keterbatasan}

Penelitian ini telah diusahakan dan dilaksanakan sesuai dengan prosedur ilmiah, namun demikian masih memiliki keterbatasan seperti penelitian ini tidak komprehensif karena hanya melihat kinerja SIPKD dan tidak mencapai keseluruhan sistem informasi yang berada di BKD, penelitian ini terdapat keterbatasan waktu sehingga ada kemungkinan hasil penelitian yang diharapkan belum maksimal.

C. Saran

Berdasarkan hasil penelitian ini diharapkan penelitian selanjutnya diharapkan semua narasumber staff pranata IT di BKD dapat dilakukan wawancara yang lebih mendalam dan periode wawancara diperpanjang serta dimasa-masa narasumber sedang tidak sibuk bekerja. Bagi yang berminat pada penelitian selanjutnya dapat melakukan audit sistem informasi seluruh sistem dan subsistem informasi yang dapat mempengaruhi output SIPKD.

\section{Daftar Pustaka}

[1] “Gartner Market Databook, 1Q18 Update,” www.gartner.com, 2018. .

[2] M. A. F. Hakim, "Hilangnya Uang Nasabah BRI Kediri Diduga Mengalir ke Luar Negeri," kompas.com, 2018. .

[3] T. Kurnia, "Jutaan Data Pengguna Aplikasi Transportasi Online Ini Bocor," liputan6.com, 2018. .

[4] P. K. Salatiga, "Laporan Kinerja Instansi Pemerintah (LKjIP) Kota Salatiga Tahun 2017," Salatiga, 2018.

[5] R. A. Fajrin, Murahartawaty, and S. F. S. Gumilang, "Perancangan Tata Kelola Teknologi Informasi di BAPAPSI Pemkab Bandung Menggunakan framework COBIT 5 Pada Domain EDM dan DSS,” J. Inf. Syst. Eng. Bus. Intell., vol. 2, no. 2 , pp. 74-80, 2016.

[6] D. Ciptaningrum, E. Nugroho, and D. Adhipta, "Audit Keamanan Sistem Informasi Pada Kantor Pemerintah Kota Yogyakarta Menggunakan Cobit 5," vol. 2015, no. Sentika, p. 6, 2015.

[7] dan A. S. Abdul Hakim, Hoga Saragih, "Evaluasi Tata Kelola Teknologi Informasi Dengan Framework COBIT 5 Di Kementrian ESDM (Studi Kasus pada Pusat Data dan Teknologi Informasi ESDM)," vol. 12, pp. 108-117, 2014.

[8] B. Supradono, "Tingkat Kematangan Tata Kelola Teknologi Informasi ( It Governance ) Pada Layanan Dan Dukungan Teknologi Informasi ( Kasus: Perguruan Tinggi Swasta Di Kota Semarang )," Semin. Nas. Teknol. Inf. dan Komun. Terap., vol. 2011, no. Semantik, pp. 0-6, 2011.

[9] N. Azizah, "Audit Sistem Informasi Menggunakan Framework COBIT 4.1 Pada ELearning UNISNU Jepara," vol. 8, no. Vol 10 No 2 (2014): Jurnal Sistem Informasi 
AITI: Jurnal Teknologi Informasi

Volume 16 No. 1 Februari 2019, 65-87

(Journal of Information System), pp. 1-10, 2017.

[10] ISACA, “COBIT 5 ISACA's new framework for IT Governance, Risk, Security and Auditing An overview," ISACA Whitepapers, p. 39, 2013.

[11] Badan Keuangan Kota salatiga, "Struktur Organisasi," Badan Keuangan Kota Salatiga, 2019. . 